Journal of Science
http://dergipark.gov.tr/gujs

\title{
A Comparative Research on Space of Women in Prayer Place Interiors of Celestial Religions: Cases from Istanbul
}

\author{
Gulsen DISLI',*(D), Zuhal OZCAN ${ }^{2}$ (D) \\ ${ }^{I}$ Necmettin Erbakan University, Department of Architecture, 42140, Konya, Turkey. \\ ${ }^{2}$ Çankaya University, Department of Interior Architecture, 06530, Ankara, Turkey.
}

\author{
Highlights \\ - Gendered architecture in sacred spaces of celestial religions. \\ - Gendered segregation in synagogues, churches, and mosques. \\ - Women's prayer places have acknowledged separation from men's part in prayer place interiors. \\ - Cross-cultural comparison via structured architectural space and basic terminologies. \\ - Result analysis of architectural gendered space in celestial religions.
}

\begin{tabular}{|c|}
\hline Article Info \\
\hline $\begin{array}{l}\text { Received: } 11 / 06 / 2019 \\
\text { Accepted: 08/10/2019 }\end{array}$ \\
\hline Keywords \\
\hline $\begin{array}{l}\text { Women's Prayer Space } \\
\text { Gendered Architecture } \\
\text { Segregation } \\
\text { Celestial Religions } \\
\text { Cross-cultural } \\
\text { comparison }\end{array}$ \\
\hline
\end{tabular}

\section{INTRODUCTION}

The relationship between gender and space is a theme used in the field of architecture, as well as the histories of gender and women studies over many years. There is also scholarly interest in the topics of gender and sacred spaces and considerable professional concern is being put into identifying the place of women and issue of gender segregation in places of worship [1-9]. Yet, their relationship with regard to architectural point of view has not always explicitly stated, let alone comparative analysis of gendered sacred spaces in celestial religions. However, every religion arranged special architectural solutions to place women in sacred spaces peculiar to its nature. According to Mazumdar and Mazumdar spacious prayer halls, congregation, and the division of prayer place into separate parts for men and women in Muslim mosques and Orthodox Jewish synagogues are important requirements in mosque and synagogue designs [10]. However, a systematic analysis of women's sections in synagogue, church, and mosque interiors is lacking. Hence, this article reviews existing literature to identify and describe how women's attendance to

\begin{abstract} gendered architecture in prayer places of celestial religions, namely Judaism, Christianity, and Islam. Hence, this study aims to reveal how attendance of women in prayer places with different national, historic, religious, and cultural characteristics shaped architectural space organization relig assess potential similarities and differences of women's section in prayer spaces of celestia observations. In addition to general observations in building scale, some exemplary historic synagogues, churches, and mosques in Istanbul still in use have been chosen as case studies, and their plan typologies, as well as types and locations of women's galleries/sections have been prayer places as a structured architectural space and basic architectural terminologies used to define women's section. The major conclusion of the study is that originally women had right to worship in prayer spaces without any physical separation in all three religions, yet in time the place of women had a more defined/divided/structured character especially in Islam and Judaism.
The study also indicates that while at present day, gendered architecture is still the predominant approach in Islam and in Orthodox Judaism; mix congregation in a single-unsegregated space for both sexes is more common in contemporary society of Christianity.
\end{abstract}


the synagogues, churches, and mosques influenced the architecture of these sacred spaces. However, the research neither attempts to be a comprehensive study of this field nor intends to make a detailed typological analysis of women's spaces in terms of their plan arrangement. Instead, the study presents typological analysis of some case study examples in Istanbul in terms of only their plan typologies, and types and locations of women's sections, and examines various examples of prayer places from the world belonging to all three religions. Thus, the research aims to enable the reader to gain insight into the typological variations of women's sections of sacred spaces with particular cases from Istanbul, and also aims to draw comparisons on the development of gendered architecture in prayer places of Judaism, Christianity, and Islam from their start to date.

\section{MATERIAL AND METHODS}

In order to deal with the subject of "space of women" in prayer places of celestial religions and to be able to make a cross-cultural comparison in that respect, one first needs to clarify the basic comparison methods. Therefore, "developments of women's section in prayer places as a structured architectural space" and "basic architectural terminologies used to define women's sections" are determined to be main comparison and evaluation parameters. In order to clarify the issue; synagogue, church, and mosque examples have been chosen from Istanbul, Turkey, which offers especially instructive cases.

\subsection{Parameter 1: The Development of Women's Section as a Structured Architectural Space in Celestial Religions}

In this section, it is focused on the development of women's section as a structured architectural space in prayer places of three celestial religions from start to date (Table 1). Although some exemplary synagogues, churches, and mosques in Istanbul have been chosen in order to show different plan types of women's section in prayer places, they do not exhibit whole typologies, but a small part of it.

Table 1. Primary places of worship in three celestial religions

\begin{tabular}{|c|c|c|c|}
\hline \multirow[b]{3}{*}{ 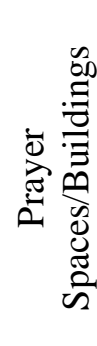 } & \multicolumn{3}{|c|}{ Celestial Religions } \\
\hline & Judaism & Christianity & Islam \\
\hline & $\begin{array}{l}\text { Wailing wall (the only } \\
\text { remaining part of the Second } \\
\text { Temple) } \\
\text { Synagogues } \\
\text { Small -scale synagogues } \\
\text { (havra) }\end{array}$ & $\begin{array}{l}\text { Cathedrals } \\
\text { Churches } \\
\text { Monasteries } \\
\text { Chapels } \\
\text { Shrines }\end{array}$ & $\begin{array}{l}\text { Jumu'ah mosques } \\
\text { Mosques } \\
\text { Masjids } \\
\text { Open-air/roadside prayer } \\
\text { spaces (namazgâh) }\end{array}$ \\
\hline
\end{tabular}

The Space of Women in Prayer Places of Judaism: The Jewish prayer space mainly called as synagogue is based on the Greek term meaning "meeting place" or "house of prayer" [11]. In addition, in Egypt, as the 2nd century BCE, the term synagogue was used meaning "place of prayer" [12]. Other common terms in antiquity used in the sense of synagogue were "school, holy place, holy enclosure, sanctuary, dwelling place, amphitheater, and Sabbath meeting place" [12]. Exact date of first synagogues is uncertain, though there are assumptions about their origins extending to the Babylonian exile, and some others dating to the 3rd or 2nd century BCE [12]. According to Gutmann the emergence of synagogue was in the 2nd century BCE after the Hasmonean Revolt [13]. Second Jewish Temple in Jerusalem was built in the 6th century $\mathrm{BCE}$ and destructed in $70 \mathrm{CE}$. After its destruction the Jews spread various parts of the world [14], and synagogues as the places of worship, education, meeting, accommodation, courthouse, and holy feasts became primary prayer places of Jews [15]. As Brooten stated both literary and archaeological evidences suggest that when first built there were no explicit evidence of physical permanent architectural separations/dividers such as women's gallery, section, side room, or partition wall in synagogues, though it was certain from ancient sources that women attended regularly at synagogue prayer services [16]. According to Safrai, women were even more active in congregational services in history than they are today and in Halakah; women are obliged to pray, synagogue being one of the places to fulfil this obligation [34]. Archaeologically, there was no gallery or separate section for women in the earliest Temple in Israel. 
According to Brooten although Second Temple had a women's forecourt, this part had a segregated usage by both sexes only during a special day celebrated once a year [16].

Similarly, the side rooms assigned to women in Diaspora Synagogues had no evidence coming from the building itself. Brooten and Milson suggest that a few galleries observable in early synagogues from 4th 5 th centuries might not have served to function as women's section [16-17]. Moreover, the idea about the existence of a separate entrance for women in the early Byzantine period synagogues has not been confirmed [17-18]. Similarly, Strange asserts that ancient texts and archaeological evidence reveal no gallery or separate entrance for women in ancient synagogues, namely there is no provision for gendered space in ancient synagogue architecture $[12,19]$. However, scholars argue that architectural separation of gender in synagogues probably did not begin to occur until the late 6th century $[17-18,20]$.

Mann mentions about 'the relationship of the separate women's seating to that of the men' among the common set of the design issues in medieval and modern synagogues until the 19th century [21]. For instance in Ben Ezra Synagogue (rebuilt in 1039-1041) in Cairo, there were galleries for women above the aisles reached through a separate entrance. Likewise, another medieval synagogue dated ca. 1314-1315 in Cordoba, and El Transito Synagogue in Toledo (built 1357-60), had a women's gallery above the vestibule fronting the main hall with arched openings, and a women's gallery along one side of the single-hall, respectively [21]. As other Gothic examples; a medieval synagogue built in 1174-1175 CE in Worms had a women's section called as Frauenschul added in 1212-1213 CE with narrow slit openings on the main synagogue in Central Europe. Similarly a Gothic synagogue of Altneuschul of Prague dated ca. 1265 CE had a 14th century Frauenschul addition. Another synagogue at Sopron in western Hungary had a Frauenschul built at the same date with the synagogue ca. in 1330s [21]. Pinkas Synagogue of 13th century in Italy also had a women's balcony addition dated to the early 17 th century. It is also worth mentioning that according to an old document dated 1709, in Pinkas Synagogue, men and women owned individual seats with women's outnumbering the men's that could be bought, sold, and left for inheritance. In Remo Synagogue (built 1553) in Cracow, women's gallery was separated from the men's area with a later addition of arcaded Tuscan columns, and Scuola Grande Tedesca Synagogue of Venice (built 1528-1529) has an elliptical women's gallery. In Touro Synagogue of 18th century in Rhode Island, USA, there are women's galleries on three sides of main prayer area [21]. Different from the medieval times, in 16th- 17th century Venice, Jewish women prayed at the same hall with men just separated with balustrades or perforated screens, and in 17th century European synagogues unlike from the modern Orthodox practice, men and women occupied different sections of the gallery with perforated screens on women's side [21].

To conclude, the current consensus among the scholars is that throughout late antiquity, synagogue attendance was a regular custom for women without any segregation in any manner from men [20, 22]. It was in late 6th century that architectural segregation started and after the 14th century women's section in synagogues acknowledged different variations at different parts of the Jewish settlements [21]. In addition, in 19th century, there were different applications on the places of women in synagogues during worship. Though the Reformist congregation gave permission to women to pray together with men in the main hall, conservative congregations continued to separate women from men's arena and forced them to pray at the segregated places reserved for them. In some other congregations, this strict separation was softened by removing partition elements such as wooden lattices, curtains, and partition walls of the women's gallery [23]. It is not known exactly when the Jews came to Anatolia. Yet it is suggested that the first Jews might have come to Anatolia during the Babylonian Exile between 586-538 BCE, with the right to build synagogues for worship and this Jewish society was named as Romaniots [15]. Especially in western Anatolia, there are traces of Jewish settlements and documents belonging to the 4th century BCE, and it was in 1326 when Jews first encountered with Ottomans in Bursa [24]. Later, since 1492, Jews, who were dismissed from Spain, were settled in Istanbul (Constantinople), Edirne (Adrianapolis), Thessalonica, and Izmir with the order of Ottoman Sultans [14, 24]. Golden Horn, or with its modern Turkish name Haliç, a natural harbor, was the first settlement of Jews in Istanbul, including one of the oldest synagogues dated 4th -5th centuries in Halkoprateia or today's Sirkeci area [25]. Throughout history, it is estimated to be existed thirty-eight synagogues in Istanbul, where Jewish population mostly settled in Turkey. Today, among the remaining thirty synagogues in Istanbul, just nineteen are used in their original function [24-26] (Table 2). In all these synagogues, existence of women's section is one of the primary architectural features 
[25]. Either are there galleries in octagonal, four-sided elliptical, rectangular, $U$ shape, balconies, floors for women congregation or women pray in the main hall with men but at a separate side (generally left) of the synagogue [11] (Table 2). In addition to aforementioned place arrangements, in Haskoy Karaite Synagogue in Beyoglu, Istanbul, for instance, front-back positioning of sexes was also observable, where women were located behind the men, with bare foot and veiled, in early 1990s. Even before that date, there were special compartments for women separated with wooden dividers [27].

Table 2. Date, location, typology, and schematic drawings of case study synagogues in Istanbul, and type/location of women's section in these building

\begin{tabular}{|c|c|c|c|c|}
\hline \multicolumn{5}{|c|}{ Some exemplary historic synagogues in Istanbul still in use } \\
\hline $\begin{array}{l}\text { Name of } \\
\text { the } \\
\text { synagogue }\end{array}$ & $\begin{array}{c}\text { Location/ built } \\
\text { date }\end{array}$ & $\begin{array}{l}\text { Synagog } \\
\text { ue } \\
\text { typolog } \\
\text { y }\end{array}$ & $\begin{array}{l}\text { Schematic drawing of the } \\
\text { synagogue with galleries/ } \\
\text { women's section shown in } \\
\text { pink color }\end{array}$ & $\begin{array}{l}\text { Type/location of } \\
\text { galleries }\end{array}$ \\
\hline $\begin{array}{l}\text { Neve } \\
\text { Shalom } \\
\text { Synagogue }\end{array}$ & $\begin{array}{l}\text { Galata/ } \\
1938\end{array}$ & $\begin{array}{l}\text { Central } \\
\text { plan } \\
\text { type }\end{array}$ & & $\begin{array}{l}\text { Octagonal gallery with } \\
\text { splayed corners above } \\
\text { the main hall. }\end{array}$ \\
\hline $\begin{array}{l}\text { Italian (Kal } \\
\text { De Los } \\
\text { Frankos) } \\
\text { Synagogue }\end{array}$ & $\begin{array}{c}\text { Galata/ } \\
\text { First built: } \\
1862 \\
\text { rebuilt: } 1931\end{array}$ & $\begin{array}{l}\text { Basilical } \\
\text { plan } \\
\text { type }\end{array}$ & & $\begin{array}{l}\text { Elliptical gallery above } \\
\text { the main hall. }\end{array}$ \\
\hline $\begin{array}{l}\text { Ahrida } \\
\text { Synagogue }\end{array}$ & $\begin{array}{l}\text { Balat/ Early } \\
\text { 15th century }\end{array}$ & $\begin{array}{l}\text { Central } \\
\text { plan } \\
\text { type }\end{array}$ & & $\begin{array}{l}\text { Rectangular gallery with } \\
\text { arched openings to the } \\
\text { west wall of the main } \\
\text { hall. Separate entrance } \\
\text { door for women. }\end{array}$ \\
\hline $\begin{array}{l}\text { Yanbol } \\
\text { Synagogue }\end{array}$ & $\begin{array}{c}\text { Balat/ First } \\
\text { built in } \\
\text { Byzantine } \\
\text { Period, Rebuilt } \\
17^{\text {th }}-18^{\text {th }} \text { cc. }\end{array}$ & $\begin{array}{l}\text { Central } \\
\text { plan } \\
\text { type }\end{array}$ & =. & $\begin{array}{l}\text { L shape gallery along } \\
\text { the north and west wall } \\
\text { of the main hall. It is } \\
\text { reached with exterior } \\
\text { stairs. }\end{array}$ \\
\hline $\begin{array}{l}\text { Hesed Le } \\
\text { Avraam } \\
\text { Synagogue }\end{array}$ & $\begin{array}{c}\text { Buyukada/ } \\
1904\end{array}$ & $\begin{array}{l}\text { Simple } \\
\text { quadrila } \\
\text { teral } \\
\text { plan } \\
\text { type }\end{array}$ & & $\begin{array}{l}\text { U shape gallery with } \\
\text { curved corners to the } \\
\text { north, south, and west } \\
\text { wall of the main hall. }\end{array}$ \\
\hline $\begin{array}{l}\text { Bet Nissim } \\
\text { Synagogue }\end{array}$ & $\begin{array}{c}\text { Kuzguncuk } \\
/ \\
1840 \text { s }\end{array}$ & $\begin{array}{l}\text { Central } \\
\text { plan } \\
\text { type }\end{array}$ & 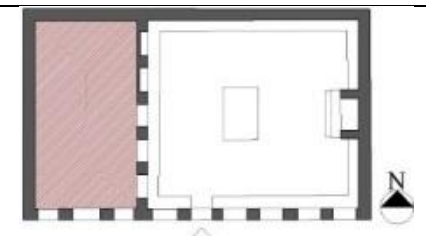 & $\begin{array}{l}\text { Rectangular gallery to } \\
\text { the west of the main } \\
\text { hall. }\end{array}$ \\
\hline
\end{tabular}

All above-mentioned statements show that regarding the space of women in prayer places of Judaism, at the beginning there was not a concrete, physical, architectural separation of sexes in sacred spaces. Yet, case study examples from Istanbul at least prove the existence of separate spaces allocated for women in synagogues.

The Space of Women in Prayer Places of Christianity: The word church comes from a Greek term ekklēsia used for the gathering of Jewish community especially for a religious purpose and in the New Testament it is used in a more general context comprising the whole Christian believers in the world or a body or organization of them [28]. Consensus among scholars is that, originally the sexes were not 
separated in churches since many sources affirm the interaction of men and women during times of worship, however, in time because of the church orders, decorum, security reasons, gender discrimination, and need for paternalistic protection (to hide the beauty of female worshipper), certain places in churches were assigned to women [29-30]. Based on the words of St. Paul, Douglas stated that the women had the freedom and equality in primitive church of the Acts [31]. However, different from early periods, sources from early middle Ages point out the gendered divisions of women on the north or left side and men on the south or right side within the church interiors [6]. According to Schelif, segregation of women and men in medieval churches was a necessity for the protection of women from unpleasant conditions especially considering the crowd of congregation during the worship [6]. This longitudinal separation of genders is governed by convention throughout medieval and early modern times and is still a practice applied in some rural churches of Europe [32]. Such placement was common especially in the United States and Canada and implemented into the 20th century [6]. The association of women with the north side of the church was also a pattern observed in the cemeteries of churchyards. Archaeological evidence suggested that this gendered burial pattern extended up to the 13th century in Sweden, and even ceased earlier in elsewhere [32]. Yet, it will be erroneous to generalize this custom surviving since the early Christian period. Instead, what was common was front/back positioning of laity with women behind men [6, 30]. Regarding the galleries over the aisles, areas reserved for women in order to watch the service, Stewart notes that in England and France, most of the Romanesque churches (6th-10th century) have galleries as wide as the aisles below them, the exact reason of which is unknown, and all large Byzantine churches had galleries for women [33]. However, in Rome, only the Basilica of Saint Agnes (7th century) and Basilica of Saint Lawrence both outside the walls (6th century) have galleries and for centuries in Italy the churches did not include galleries until their reintroduction after the 11th century CE [33]. Instead of galleries there were examples from 7 th century churches with median dividing walls. For instance, 15th century illustrations from Italy, demonstrates gendered spatial arrangements in churches during sermons even held outdoors divided with curtains [6]. Though monasteries are not the target area of this study, the situation was the same in Late Medieval nunneries, in which separate cloisters and a common church with separate entrances and a longitudinal dividing wall at the center for the separation of nuns and canons were observable [32]. The Russian Pilgrim Ignatius of Smolensk also confirmed continuous use of galleries by women during services and existence of gallery curtains in Hagia Sophia, Istanbul, and their rationale in late 14th century [29-30]. Taft also mentions about the sources dated to the 10th and 14th centuries about concealing of women behind the gallery curtains, by further asserting the discontinuity of this practice considering the earlier or later texts confuting the hiding practice of women behind the curtains [30].

At present, in general women and men sit wherever they want in the main nave area without any seat reservation during the service. However, in Coptic churches women sit separately from men and typically wear Western clothing, yet in rural settlements wear veils like many Muslim women. Similarly, in Eastern Orthodoxy, though no longer a universal custom, in some places, women wear a veil or head covering and sit separately in church [34-35]. In Brazil's oldest Pentecostal church, also, men and women sit on separate sides and women wear veil during worship [36]. Similarly, in Orthodox churches of Istanbul, where Finnish Orthodox have been directly connected not long ago, either the rectangular galleries above the narthex, or $\mathrm{U}$ and L shape balconies to the west, north, and south of the main nave area are reserved for women [37]. Yet, it is not always a strict rule for women to use those structured spaces during the worship as in Holy Trinity (Hagia Triada) Greek Orthodox Church, in Beyoglu, Istanbul, where women could sit on pews together with men in main nave area during worship (Table 3, Figures 1-2). Similarly in Antakya patriarchate, women's part at the upper floor has no longer been used, since nearly all users of the church are relatives, therefore prefer to use ground floor during worship [37]. 
Table 3. Date, location, typology, and schematic drawings of case study churches (women's galleries are in pink color) in Istanbul and type/location of women's section in the buildings

\begin{tabular}{|c|c|c|c|c|}
\hline \multicolumn{5}{|c|}{ Some exemplary historic churches in Istanbul Still in use } \\
\hline $\begin{array}{l}\text { Name of the } \\
\text { church }\end{array}$ & $\begin{array}{l}\text { Location/ } \\
\text { built date }\end{array}$ & $\begin{array}{l}\text { Church } \\
\text { typolog } \\
\text { y }\end{array}$ & $\begin{array}{l}\text { Schematic drawings of } \\
\text { the churches with }\end{array}$ & Type/location of galleries \\
\hline $\begin{array}{l}\text { Patriarchal } \\
\text { Church of St. } \\
\text { George }\end{array}$ & $\begin{array}{l}\text { Phanar } \\
\text { (Fener)/ } \\
1600\end{array}$ & $\begin{array}{l}\text { Three- } \\
\text { aisled } \\
\text { basilical } \\
\text { plan } \\
\text { type }\end{array}$ & & $\begin{array}{l}\mathrm{L} \text { shape gallery to the west and } \\
\text { extending partly to the north } \\
\text { above the main nave area. }\end{array}$ \\
\hline $\begin{array}{l}\text { Holy Trinity } \\
\text { (Hagia } \\
\text { Triada) } \\
\text { Greek } \\
\text { Orthodox } \\
\text { Church }\end{array}$ & $\begin{array}{l}\text { Beyoglu- } \\
\text { Taksim/ } \\
1880\end{array}$ & $\begin{array}{l}\text { Three- } \\
\text { aisled } \\
\text { basilical } \\
\text { plan } \\
\text { type }\end{array}$ & & $\begin{array}{l}\text { U shape gallery to the west and } \\
\text { extending partly to the north } \\
\text { and south above the main nave } \\
\text { area. }\end{array}$ \\
\hline $\begin{array}{l}\text { Beyoglu Üç } \\
\text { Horan } \\
\text { Armenian } \\
\text { Church }\end{array}$ & $\begin{array}{l}\text { Beyoğlu / } \\
\text { 16th } \\
\text { century }\end{array}$ & T type & & $\begin{array}{l}\text { Rectangular gallery above the } \\
\text { narthex to the west of the main } \\
\text { nave area. }\end{array}$ \\
\hline $\begin{array}{l}\text { Belgradkap1, } \\
\text { Panagia } \\
\text { Church }\end{array}$ & $\begin{array}{l}\text { Belgradk } \\
\text { ap1, } 1523\end{array}$ & $\begin{array}{l}\text { Three- } \\
\text { aisled } \\
\text { basilical } \\
\text { plan } \\
\text { type }\end{array}$ & & $\begin{array}{l}\text { Rectangular gallery on south- } \\
\text { north direction above the } \\
\text { narthex, to the west of the main } \\
\text { nave area. The gallery is } \\
\text { reached via stairs on the south } \\
\text { side of the narthex. }\end{array}$ \\
\hline $\begin{array}{l}\text { Sarmasik, } \\
\text { Hagios } \\
\text { Demetrios } \\
\text { Church }\end{array}$ & $\begin{array}{l}\text { First built } \\
\text { in } 17 \text { th } \\
\text { century, } \\
\text { rebuilt in } \\
1834\end{array}$ & $\begin{array}{l}\text { Three- } \\
\text { aisled } \\
\text { basilical } \\
\text { plan } \\
\text { type }\end{array}$ & & $\begin{array}{l}\text { Rectangular gallery on south- } \\
\text { north direction to the west of } \\
\text { the main nave area. The gallery } \\
\text { is reached via stairs on the } \\
\text { northwest side of the nave. }\end{array}$ \\
\hline $\begin{array}{l}\text { Silivrikap1, } \\
\text { Panagi } \\
\text { Church }\end{array}$ & $\begin{array}{l}\text { First built } \\
\text { in late } 5^{\text {th }} \\
\text { early } 6^{\text {th }} \\
\text { c., } \\
\text { rebuilt in } \\
924\end{array}$ & $\begin{array}{l}\text { Three- } \\
\text { aisled } \\
\text { basilical } \\
\text { plan } \\
\text { type }\end{array}$ & & $\begin{array}{l}\text { Rectangular gallery on south- } \\
\text { north direction above the } \\
\text { narthex, to the west of the main } \\
\text { nave area. The gallery is } \\
\text { reached via stairs on exterior } \\
\text { northwest wall of church. }\end{array}$ \\
\hline
\end{tabular}
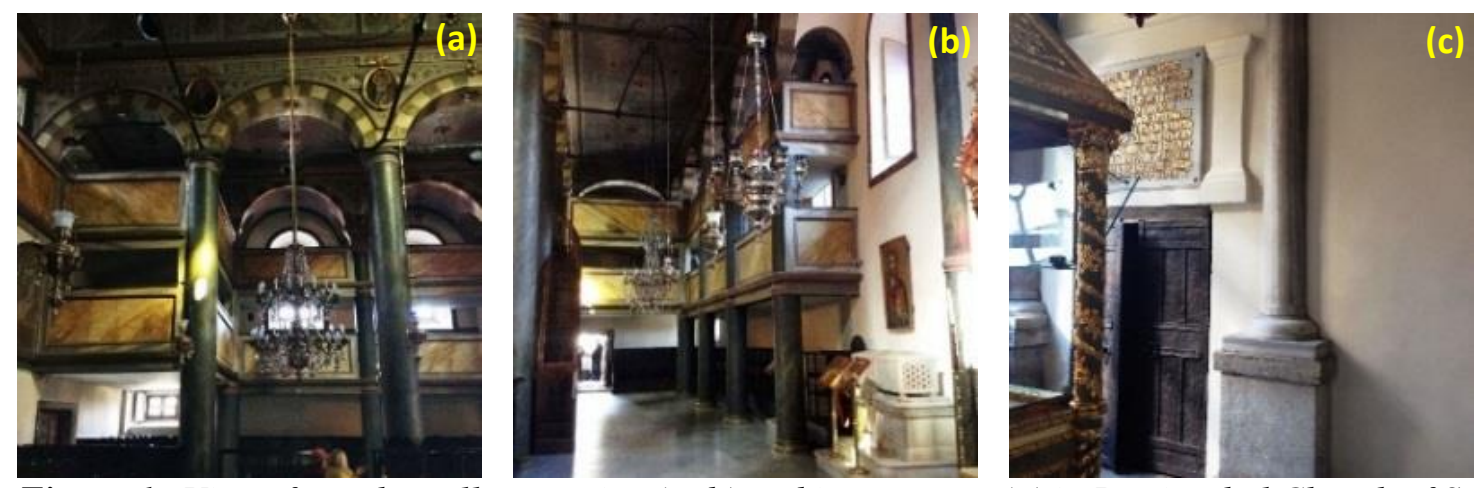

Figure 1. Views from the gallery section $(a, b)$ and its entrance $(c)$ in Patriarchal Church of St. George in Phanar, renovated 1600, Istanbul, Turkey. Photograph by Authors, 2017 

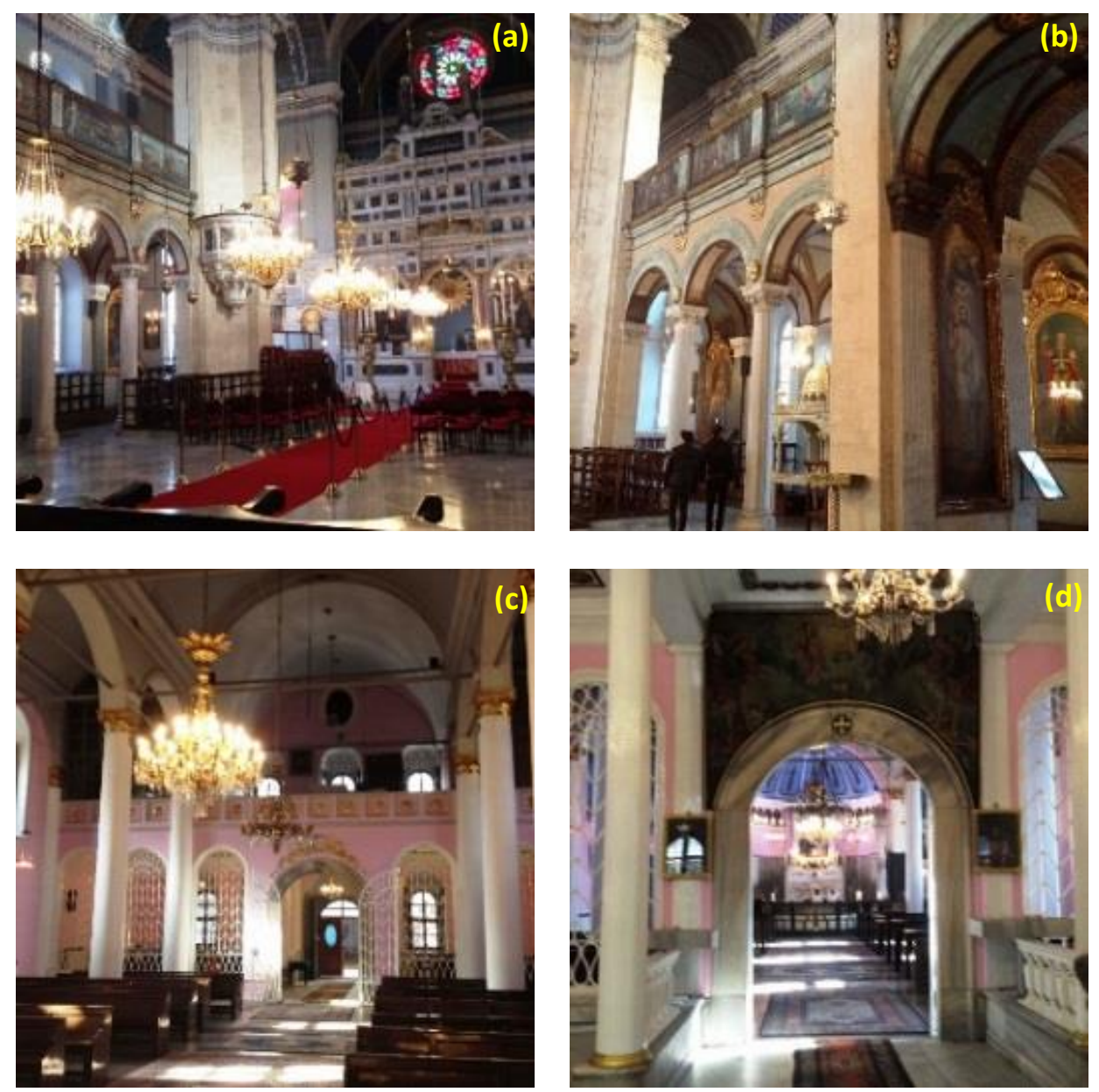

Figure 2. Views from the gallery section ( $a-b)$ in Holy Trinity (Hagia Triada) Greek Orthodox Church, built 1880, and views from the gallery section (c-d) in Surp Hresdogabad Church, rebuilt 1835, Istanbul, Turkey. Photograph by Authors, 2015, 2017

The space of Women in Prayer Places of Islam: Prayer places of Islam, mosques/masjids, are defined as "places where one prostrates oneself in worship" [38]. The term masjid was found in Aramaic as early as the 5th century BCE, and later in Nabataean inscriptions meaning "place of worship". The terms alMasjid'al Haram and al-Masjid'al Aksa were then used in Meccan period referring Mecca sanctuary and Jerusalem sanctuary, respectively [38]. Regarding the attendance of women to the mosques at the time of Prophet Muhammad (571-632 CE), it can be inferred from the hadiths that women should not be prevented from going to masjids, but they should not be perfumed, should form a separate line behind the men at the last rows and should leave masjids via a separate door before male congregation after prayer [39]. But, it should be noted that the function of that separate door was to help ease the entrance and exits of women congregation to the masjid, not to separate them from the male congregation, such that in Sunan Abu Dawud in The Book of Salât (The Parayer) in Chapter 17, it is clearly stated that; "The Messenger of Allah said: 'Why don't we leave this door (in the Masjid) for the women" [39]. Hence, it is certain that in Prophet's Mosque in Medina dated to early 7th century, there was not a separate section for women except for a separate door called as Bab-an Nisa and front/back positioning during the prayer [40-41]. In addition, Islamic religious scripts clearly indicate that, especially in Hanafi Sect, in order to provide conformity in prayer alignments, and in order to prevent the existence of inconvenience situations during the prayer, female congregation are to pray at the rearmost row of male prayers, or else the prayer of male congregation on the same row with the female will not be valid, namely, it is a must for male congregation not to align on the same row with the female during the prayer [42-43]. In his book Reddü'l Muhtar, İbn Abidin indicated that the arrangement of rows during the prayer should be as follows; first the men, then the child and elderly, and at the rearmost row women congregation should pray [43]. On the contrary, in Shafi'i Sect, prayer of women on the same row with men will not harm the prayer of male congregation [42]. In Islam, in a mosque, the whole space is designed as clearly visible and homogeneous in all its parts, namely 
designed as a "heavenly theater" which refers to the "unique function of the mosque as the place for communal prayer", and in this bare space, imam performs the prayer together with the congregation [44]. During the congregational prayers, imam and the congregation should be in the same bare space in the mosque, and there should be no audial obstacle preventing to hear the sound of the imam [45]. Hence, in order to make the sound of the imam heard evenly by the whole congregation, especially in Sinan's mosques, some water jugs were located inside the domes of the mosques [44]. Therefore, it can be interpreted that privacy and audial requirements rather than prohibition in Islam necessitate gendered segregations in the mosque interiors [46]. The tradition of front/back congregation at the unsegregated space continued during the era of the four Caliphs (632-661 CE) [41]. However, in Umayyad period (661$750 \mathrm{CE}$ ) maksuras emerged first for the protection of rulers and then in order to conceal women during the prayer [38].

Later, in $870 \mathrm{CE}$ the governor of Mecca, reserved a separate space for women by tying ropes between the columns $[38,47]$. This gender segregation in mosques became clearer in later periods with different architectural types such as mezzanines, separate courtyards, galleries, balconies, and maksuras. Samb indicates that, mezzanines at the four angles of the court in Quwwat-ul-Islam Mosque (built $1192 \mathrm{CE}$ ), Delhi, and the upper floors of Afzal Khan's Mosque (built 1653), Afzalpur, and Anda Masjid (built 1608), Bijapur, were possibly built for women [38]. In Aksa Mosque in Jerusalem, there were three maksuras for women about 912-913 CE, and the incomplete mosque Hasan in Rabat, Morocco began in $1195 \mathrm{CE}$ had separate courtyards intended for men and women respectively [38]. In Al-Azhar Mosque (built 970 CE), Cairo, maksura was used for teaching purposes of women in Fatimid period [38].

At present day, either wooden/metal grilles, or curtains shut off a place for women in mosques (Figure 3). In other cases, second floor galleries, separate rooms/ floors (mostly basement) are reserved for them with or without separate entrances. There are also a few rare examples especially in western societies, where women and men pray together within a mix congregation leaded with a women prayer leader during prayer.
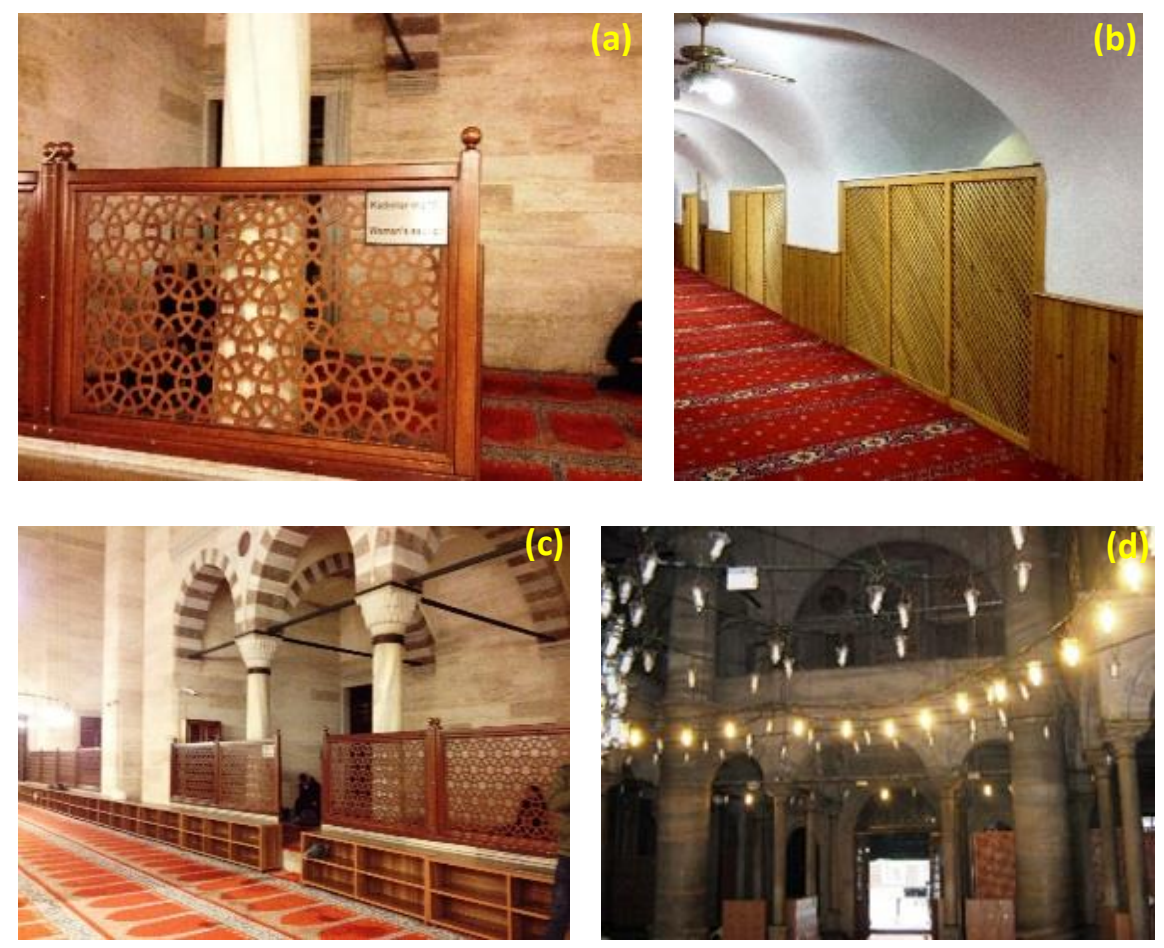

Figure 3. Women's prayer space in Suleymaniye Mosque (a-b), in Yeralt Mosque (c), and Laleli Mosque (d), in Istanbul, Turkey. Photographs by Authors, 2014-2015, 2017

Some exemplary mosques from different periods have been selected from Istanbul. In those mosques either octagonal, U shape or rectangular galleries have been allocated for women (Table 4, Figure 3). As understood from the case study mosques and literature survey, spaces allocated for women in prayer places 
of Islam are either composed on the gallery story to the north, east, and west of the main prayer hall or on a different floor/courtyard without any physical and visual contact with the main prayer area.

Table 4. Date, location, typology, and schematic drawings of case study mosques (women's sections are in pink color) in Istanbul, and type/location of women's section in the buildings.

\begin{tabular}{|c|c|c|c|c|}
\hline \multicolumn{5}{|c|}{ Some exemplary historic mosques in Istanbul still in use } \\
\hline $\begin{array}{l}\text { Name of } \\
\text { the mosque }\end{array}$ & $\begin{array}{l}\text { Location/ } \\
\text { built date }\end{array}$ & $\begin{array}{l}\text { Mosque } \\
\text { typology }\end{array}$ & $\begin{array}{l}\text { Schematic drawing of the } \\
\text { mosque with galleries }\end{array}$ & $\begin{array}{c}\text { Type/location of } \\
\text { galleries }\end{array}$ \\
\hline $\begin{array}{l}\text { Ertugrul } \\
\text { (Seyh Zafir } \\
\text { Tekke) } \\
\text { Mosque }\end{array}$ & $\begin{array}{c}\text { Besiktas/ } \\
1887\end{array}$ & $\begin{array}{l}\text { Rectangular } \\
\text { plan type }\end{array}$ & & $\begin{array}{c}\text { Octagonal gallery } \\
\text { above the main hall } \\
\text { concealed with wooden } \\
\text { latticework. }\end{array}$ \\
\hline $\begin{array}{l}\text { Laleli } \\
\text { Mosque }\end{array}$ & $\begin{array}{l}\text { Fatih/ } \\
1759- \\
1763\end{array}$ & $\begin{array}{l}\text { Square type } \\
\text { plan with } \\
\text { projecting } \\
\text { mihrap iwan }\end{array}$ & 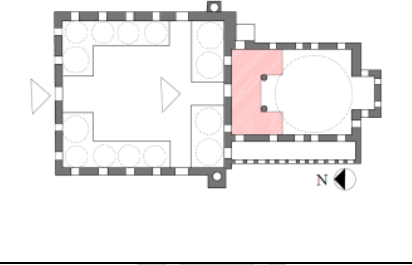 & $\begin{array}{l}\text { U shape gallery to the } \\
\text { north, and half east- } \\
\text { west walls of main } \\
\text { prayer hall reached via } \\
\text { stairs inside the north } \\
\text { wall. }\end{array}$ \\
\hline $\begin{array}{l}\text { Ahmediye } \\
\text { Mosque }\end{array}$ & $\begin{array}{l}\text { Üsküdar/ } \\
1721-22\end{array}$ & $\begin{array}{l}\text { Square plan } \\
\text { type }\end{array}$ & & $\begin{array}{l}\text { Rectangular gallery to } \\
\text { the north wall of main } \\
\text { hall with elliptical } \\
\text { front. }\end{array}$ \\
\hline $\begin{array}{l}\text { Hekimoglu } \\
\text { Ali Pasha } \\
\text { Mosque }\end{array}$ & $\begin{array}{c}\text { Fatih/ } \\
1734-35\end{array}$ & $\begin{array}{l}\text { Square type } \\
\text { plan with } \\
\text { projecting } \\
\text { mihrap iwan } \\
\text { to the south } \\
\text { of main hall }\end{array}$ & & $\begin{array}{l}\text { U shape gallery to the } \\
\text { north, and whole west- } \\
\text { east walls of main hall. }\end{array}$ \\
\hline $\begin{array}{l}\text { Molla } \\
\text { Celebi } \\
\text { (Findikli) } \\
\text { Mosque }\end{array}$ & $\begin{array}{c}\text { Beyoglu/ } \\
1570-84\end{array}$ & $\begin{array}{l}\text { Square type } \\
\text { plan with } \\
\text { projecting } \\
\text { mihrap iwan } \\
\text { to the south } \\
\text { of main hall }\end{array}$ & $\int_{N}$ & $\begin{array}{l}\text { Rectangular gallery to } \\
\text { the north of main hall. }\end{array}$ \\
\hline $\begin{array}{l}\text { Gazi } \\
\text { Ahmed } \\
\text { Pasha } \\
\text { (Topkap1) } \\
\text { Mosque }\end{array}$ & $\begin{array}{c}\text { Fatih- } \\
\text { Topkap1/ } \\
1571\end{array}$ & $\begin{array}{l}\text { Rectangular } \\
\text { plan type }\end{array}$ & 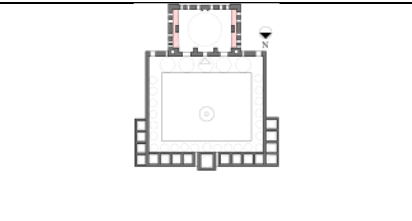 & $\begin{array}{l}\text { Rectangular galleries } \\
\text { to the whole east- west } \\
\text { walls of main hall. }\end{array}$ \\
\hline
\end{tabular}

\subsection{Parameter 2: Basic Architectural Terminologies Used to Define Women's Section in Celestial Religions}

Judaism: In Hebrew language women's section in synagogues is called as azara or ezrat nashim. Ezrat nahsim (court of women) is the women's prayer space in a synagogue, generally formed as a balcony or gallery above the main prayer area [48]. This section is one story in Sephardic synagogues and arranged as two stories in Ashkenazi examples. When it is not possible to build a gallery, either pews for women are located on a raised floor at the backside of the synagogue, or women pray behind the wooden latticework projection/divider in more conservative congregations [48]. This divider can be a curtain, screen or even shelving or plant with varying heights separating men and women during worship in some synagogues [49]. In orthodox synagogues, this separator used to divide seating arrangement is called as mehitzah. Though its exact date of existence is unclear, it was not until the reformist period that the mehitzah was first removed from the synagogue and replaced with family pews [49]. Women's court, women's gallery, women's balcony, and women's floor are the other terms used to define the section for women during prayer in a 
synagogue. At present, mixed pews, balconies, separate rooms/ floors are various seating arrangements exist in synagogues [49].

Christianity: In Byzantium, regarding the place of women in churches, sources generally locate the women in second-story aisles, namely women's galleries. In Byzantine churches those galleries generally run on three sides- north, south, and west- were called as catechumena from the 6th century on [30]. Taft asserts that in the 6th century in Egypt, catechumena were used not only by women or by catechumens, but also by men [30]. Later, the term gynaecium or matroneum meaning "place of women" was used to refer the areas of worship for women either on the ground floor of the church or on second story galleries [30, 47]. Writings around the 6th century about Hagia Sophia, Istanbul, mention about women's galleries, loggia, or women's precincts, "where the place of the women's seats appear" [30]. Mathews, however, attributes the galleries, mostly reached from the outside part of early Constantinople churches, to catechumens not exclusively to women [50]. Curtains, drapes, median-dividing walls were other separators used until early 20th century, and then the mix congregation reintroduced.

Islam: In sacred spaces of Islam, primary indicators of gendered space divisions were as follows; "maksuras, mezzanines, boundaries such as partition screens, curtains, ropes, and wooden balustrades/ grilles/ lattices in mosque interiors, galleries/balconies, or totally separate praying spaces reserved for women" [8-9]. Maksuras were enclosed chambers in the form of a box or compartment first built to protect the ruler/Sultan from hostile attacks, mostly located near the mihrab niche in the main prayer hall of the mosques [38]. The first maksuras were introduced in Umayyad period (661-750 CE) and claimed to be built in Medina in early 660s because of such an attempt to the ruler, and later spread all through Islamic lands [38]. Earliest examples of maksuras for Sultans in Anatolia were observable in Divriği Kale Mosque (built 1228-29 CE) and Beysehir Esrefoglu Mosque (built 1297-98 CE), and in Ottoman period, mosques built by sultans had a maksura in it [51]. Makasirs or zawiya, similar to maksuras were again separate compartments inside the mosques, but built for teaching, gathering and praying purposes instead of protection, and later those compartments also used by women. Maksura or mahfil is also a term used to define a gallery or balcony like projection generally located to the north of the main prayer hall of a mosque built to repeat the words of the imam by the muezzin during the prayer for the rear congregation [47, 5152]. Women's mahfil, on the other hand, is the term used for the women's section of a mosque and has similar form and location with mahfil for muezzins. Because of the limited scholarship, it is not identifiable in most of the mosques especially in Anatolia whether the mahfil is built originally for the muezzin or women [47]. Holmes-Katz's research revealed that galleries/balconies were allocated both for the rulers and noble women by the 14th century, and it was the 18th century that in major Ottoman mosques, women often used those balconies in a more standardized way [41, 47, 53].

\section{RESULTS AND DISCUSSION}

\subsection{A Comparative Evaluation of Structured Women's Spaces in Prayer Places of Celestial Religions}

Regarding the space of women in prayer places of celestial religions, general consensus among scholars is that; originally, when first emerged there was not architecture of segregation between genders neither in a mosque [39-40, 47] nor in a synagogue [3-4, 16-20] or church [6, 29-31]. Yet, based on literature and historical survey, as well as case studies on the place of women in prayer spaces; this research revealed that women congregation in sacred spaces of celestial religions acknowledged segregation at least at a certain time in history or still at present, no matter whether they were in a mosque, synagogue, or church. According to scholarship, in synagogues and churches gendered architecture was first observed in 6th century and in mosques in late 7 th century $[6,17-18,20,32,38,41]$. At present, women and men pray separately in mosques. Front/back positioning, dividers (curtain, wooden/iron partition), gallery, or a totally separate floor/area are the primary place attachment to women during prayer times. In Orthodox synagogues similarly, mehitzah, gallery, or separate floor/area are the prevalent place arrangements for women. Mix congregation with women and men at different sides in the main hall, is also rarely observable in synagogues, which was reintroduced in late 19th century [21]. Both case study synagogues in Istanbul and a new research on the ones in Israel clearly exhibit architecture of segregation at present day. As an instance, in her exhibition Baram describes "the status of women" and how they are segregated in synagogues via 
"synagogue basements, mehitzah, metal or wooden frames, curtain separators, pointed steel bars, dividers of colored glass" [46]. Similarly, in her research on the quality of women's section in three thousand mosques in Istanbul, Avc1-Erdemli revealed how inferior are the conditions of women's section compared to the men's arena [41]. In churches, compared to mosques and synagogues the situation is a little bit different at present, such that mix congregation without any front/back or left/right positioning in the main nave area is the general application during prayer except for Coptic, Orthodox, and Pentecostal churches. In churches, originally acknowledged no gendered architecture, mix congregation was reintroduced in early 20 th century $[6,32]$. Also different from front/back positioning of mosques, in synagogues and churches, left-north/right-south positioning of women and men respectively, with or without dividers is seen (Table 5). For instance, in a research on comparison of visibility quality and quantity of genders in churches, it is revealed that visual access was restricted from galleries, reserved for women towards the main nave area on ground floor, where men were located during worship [47]. Today, in mosques, Orthodox synagogues, and Coptic, Orthodox, and Pentecostal churches, different accommodations regarding the space of women causing "inequality in these sacred places" is a common situation.

Table 5. A comparative analysis of primary positioning of women in prayer places of celestial religions: M-men, W-women.

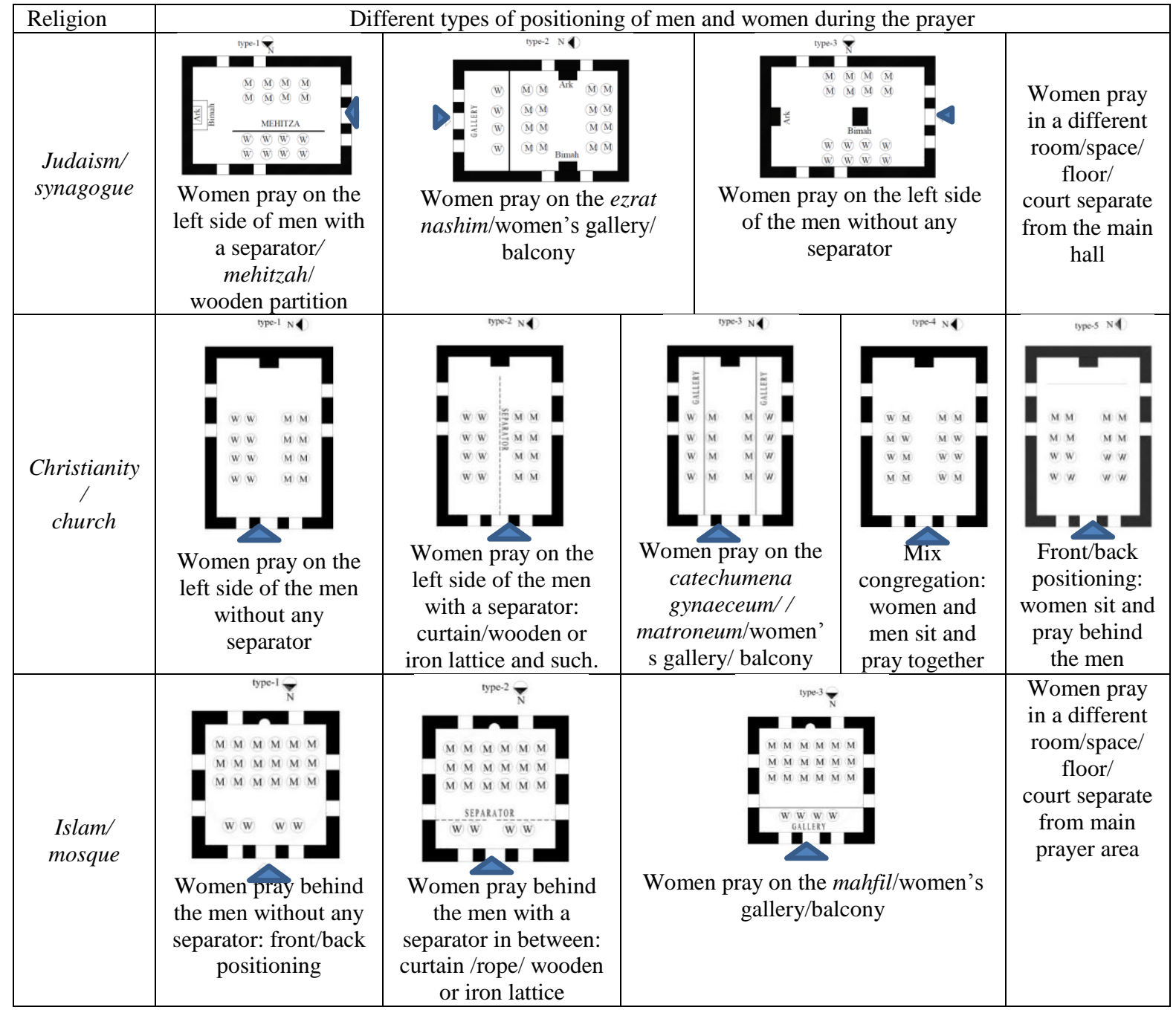

Basic possible variables of segregation and their influences are listed as; separate entrances, separate women's sections-galleries, floors, courts, quality of prayer spaces is not equal, partition elements/dividers/separators between genders, limited visual access to the liturgical foci: mihrab (mosque), chancel area (church), ark and Bema (synagogue), limited acoustical access, limited physical access to the prayer leader and to the liturgical foci [47]. 


\subsection{A Comparative Evaluation of Basic Terminologies Used to Define Women's Section in Prayer Places of Celestial Religions}

It is certain that there are both clear distinctions and similarities of terminologies used meaning women's section in places of worship among the three religions. In addition, considering different national, historic, religious, and cultural characteristics, it is also quite natural that all studied religions have their own terms and definitions for women's section. Hence, it is aimed to exhibit all these differences and similarities as a whole as shown in Table 5. While in mosques, the term maksura, makasir, or women's mahfil is used referring to the place of women in those spaces, azara or ezrat nashim is the common terminology for the synagogues, and "women's gallery" for the churches. On the other hand, women's gallery, women's balcony, women's court, and women's floor are the shared words used in all three religions expressing women's section (Table 6). Dividing elements also show similarities: curtains, drapes, or wooden partitions are used to define the structured place of women or in order to further disguise them in their galleries.

Table 6. A comparative analysis of women's sections and segregation in prayer places of celestial religions.

\begin{tabular}{|c|c|c|c|c|c|c|}
\hline 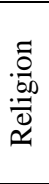 & $\begin{array}{c}\text { Depiction of } \\
\text { female figures } \\
\text { in prayer } \\
\text { places }\end{array}$ & $\begin{array}{l}\text { Existence of } \\
\text { physical } \\
\text { separation in } \\
\text { prayer places } \\
\text { in first periods }\end{array}$ & $\begin{array}{c}\text { Existence of physical } \\
\text { separation in prayer } \\
\text { places at present }\end{array}$ & $\begin{array}{c}\text { Common basic } \\
\text { terms used to refer } \\
\text { women's section in } \\
\text { prayer places }\end{array}$ & $\begin{array}{c}\text { Furnishing } \\
\text { in prayer } \\
\text { places }\end{array}$ & $\begin{array}{c}\text { Physical } \\
\text { separation } \\
\text { elements in } \\
\text { prayer places }\end{array}$ \\
\hline 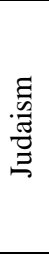 & $\begin{array}{l}\text { At present: No } \\
\text { - but, in } \\
\text { ancient } \\
\text { synagogues } \\
\text { there were } \\
\text { women } \\
\text { depictions } \\
\end{array}$ & $\begin{array}{l}\text { No: physical } \\
\text { separation } \\
\text { first started in } \\
\text { late 6th c. }\end{array}$ & $\begin{array}{l}\text { Partially exists in } \\
\text { Orthodox synagogues } \\
- \text { mix congregation } \\
\text { was reintroduced in } \\
19 \text { th c. } \\
\text { depending on region }\end{array}$ & $\begin{array}{l}\text { Ezrat nahsim, azara, } \\
\text { frauenschul, } \\
\text { women's court, } \\
\text { women's gallery, } \\
\text { women's balcony, } \\
\text { women's floor }\end{array}$ & $\begin{array}{l}\text { At present: } \\
\text { Serried rows } \\
\text { of pews or } \\
\text { chairs } \\
\text { Earlier: } \\
\text { carpet, mat }\end{array}$ & $\begin{array}{l}\text { Mehitzah, } \\
\text { wooden/ } \\
\text { iron partitions }\end{array}$ \\
\hline . & Yes & $\begin{array}{l}\text { No: physical } \\
\text { separation } \\
\text { first started in } \\
\text { early middle } \\
\text { ages (6th c.) }\end{array}$ & $\begin{array}{l}\text { Partially exists among } \\
\text { Coptic, Orthodox, and } \\
\text { Pentecostal churches } \\
\text {-mix congregation } \\
\text { was reintroduced in } \\
\text { early 20th century } \\
\text { depending on region }\end{array}$ & $\begin{array}{l}\text { Second-story aisles, } \\
\text { galleries, } \\
\text { catechumena, } \\
\text { gynaeceum, } \\
\text { matroneum, } \\
\text { women's gallery, } \\
\text { women's loggia, } \\
\text { women's precinct }\end{array}$ & $\begin{array}{l}\text { Serried rows } \\
\text { of pews or } \\
\text { chairs }\end{array}$ & $\begin{array}{l}\text { Curtains, } \\
\text { drapes, } \\
\text { wooden/ } \\
\text { iron partitions, } \\
\text { median } \\
\text { dividing walls }\end{array}$ \\
\hline$\frac{\tilde{\Xi}}{\underline{\Xi}}$ & No & $\begin{array}{l}\text { No: maksuras } \\
\text { were first } \\
\text { introduced in } \\
\text { Umayyad era } \\
\text { in late } 7 \text { th c. }\end{array}$ & Yes & $\begin{array}{l}\text { Maksura, } \text { makasir/ } \\
\text { zawiya, mahfil, } \\
\text { women's gallery, } \\
\text { women's balcony, } \\
\text { women's court, } \\
\text { women's floor }\end{array}$ & $\begin{array}{l}\text { Carpet, mat, } \\
\text { prayer rug or } \\
\text { bare floor }\end{array}$ & $\begin{array}{l}\text { Rope, curtain, } \\
\text { wooden/ } \\
\text { iron partitions }\end{array}$ \\
\hline
\end{tabular}

Although, in mosques, the entire congregation pray on the carpets, on prayer rug, or on mats with bare feet, in synagogues and churches on the contrary, congregation sit on the serried rows of pews chairs or stand still during the prayer, and they do not need to put off their shoes. Yet, in 12th century as the traveler, Petachia quoted Jews in Bagdad entered into the synagogues with bare feet and prayed on either carpets or mats. Similarly in Palestine, synagogues were furnished with carpets, and there are documents on the carpet covering of the synagogues belonging to the 9th century [54]. Regarding Jewish women in medieval Islamic cities such as Bagdad, Alexandria and Damask, from the notes of Petachia it is understood that they wore veils in 12th century, even earlier in Abbasid period (750-1258 CE), similar to Muslim women [54]. Today, similarly, married women in Israel mostly use scarfs [55]. As for the depiction of women figures, they are not observed neither in mosques nor in synagogues, but allowable in churches. Yet, Wortzman's research reveals that the situation was not the same in all ancient synagogues. Despite the prohibition by Rabbinic Law, Beit Alpha, Sepphoris and Dura Europos synagogues had mosaics and frescos depicting images of women with baring body parts [56]. 


\section{CONCLUSION}

This research identifies a little explored set of gendered architecture- the space of women in prayer placesthat are identified in three different religions, namely, Judaism, Christianity, and Islam. Religion shapes everyday lives of community and in turn underlines the power of culture and community to shape gendered architectural space arrangement, as well as women's attendance and practices in prayer places. In this study, in order to capture the role of religion in shaping women's attendance and space in synagogue, church, and mosque interiors two basic comparison and evaluation parameters were chosen; development of women's sections as a structured architectural space and basic architectural terminologies used to define those sections in prayer place interiors. On a theoretical and objective level, following results emerge:

(1) In all three religions there was no physical separation of women's space in prayer places when they first emerged, but either in 6th or 7th centuries, structured, separated spaces were began to be designed for women during worship in prayer places. This later-developed tradition is still the common application in mosques and orthodox synagogues, and even in some churches.

(2) Second-story galleries are the most common way of architectural separation if exist in all three religions.

(3) In synagogues and churches when both sexes use the same area generally, left- right positioning with or without a separator in-between is applied. In churches, front-back positioning is also observable, but what is common at present is the mix congregation. In mosques, on the other hand, female congregation has to be at the rearmost of male congregation with or without a separator, and mostly a separate gallery or floor is allocated for them.

(4) In terms of basic terminologies used to refer women's section in mosques, synagogues, and churches, literature survey findings indicated that there are both common and different terms meaning the space allocated for women, and physical separation elements are mostly curtains, drapes, and wooden/iron separators.

This research also reveals the basic possible variables of segregation and their influences; such that spaces allocated for women in prayer places have inferior conditions compared to men in terms of visual, acoustical, and physical qualities. Although it is not the aim of this research, case study synagogues, churches, and mosques of Istanbul also exhibited different possible typologies of women's spaces in all three prayer places. These variable designs and the quality of different typologies are suggested to be further studied. From all above comparative discussion and evaluation of women's spaces in prayer places of celestial religions it is possible that the comparative parameters used in this study might have transferability value during the studies in other religions in terms of gender segregation and gendered architectural issues. Though privacy, protection, and prohibition are the possible reasons for this segregated architecture, the necessities, impacts, and effects of this application need further research. Whatever the space composition and furnishing elements used are; it is a certainty that celestial religions have lead a way to the segregation of genders at least at a certain time in history or still at present in physical spaces of worship. Nevertheless, this reality is contrast with the gathering doctrines of believing exist in all three religions relevant for all human beings no matter whatever their sexes.

\section{CONFLICTS OF INTEREST}

No conflict of interest was declared by the authors. 


\section{REFERENCES}

[1] Hardy, William J., "Remarks on the History of Seat-Reservation in Churches." Archaeologia: or Miscellaneous Tracts relating to Antiquity, 53: 95-106, (1892). https://doi.org/10.1017/S026134090001122X.

[2] Aston, M., "Segregation in Church," in W.J. Sheils and Diana Wood (ed.), Studies in Church History, Oxford: Blackwell, 27: 237-294, (1990).

[3] Internet: Safrai, S., "Were Women Segregated in the Ancient Synagogue?" Jerusalem Perspective, 52: 24-36, (1997). https://www.jerusalemperspective.com/2792/, (2018).

[4] Safrai, S., "The Place of Women in First-Century Synagogues: They Were Much More Active in Religious Life Than They Are Today." The Academic Journal of CBE International: Priscilla Papers, 16(1): 9-12, (2002).

[5] Raguin, V. C. \& Stanbury, S., (eds.), Women's Space: Patronage, Place, and Gender in the Medieval Church. Albany: State University of New York Press, (2005).

[6] Schleif, C., "Men on the Right-Women on the Left: (A) Symmetrical Spaces and Gendered Places," in Virginia Chieffo Raguin and Sarah Stanbury (eds.), Women's Space: Patronage, Place, and Gender in the Medieval Church, 207-249. Albany: State University of New York Press, (2005).

[7] Tibbetts-Schulenburg, J., "Space, Sacred: And Church," in Margaret C. Schaus (ed.), Women and Gender in Medieval Europe: An Encyclopedia, 771-773. New York, NY: Routledge, (2006).

[8] Dişli, G., "Cultural Heritage and Gender: On TheTraces Of Women's Prayer Space In Bitola Mosques", Online Journal of Art and Design, 5(2): 20-37, (2017).

[9] Dişli, G., "Women's Prayer Space in the Case Studies of the Historic Mosques in Three Balkan Countries", Prostor: a Scholarly Journal of Architecture and Urban Planning, 23(2/50): 196-207, (2015).

[10] Mazumdar, S. and Mazumdar, S., "Religion and Place Attachment: A Study of Sacred Places." Journal of Environmental Psychology, 24(3): 385-397, (2004). https://doi.org/10.1016/j.jenvp.2004.08.005.

[11] Türkoğlu, İ, "Yahudi Geleneğinde Sinagog.” Toplumsal Tarih, 112: 10-17, (2003).

[12] Strange, J. F., "Synagogues, Ancient Times," in Jacob Neusner, Alan J. Avery-Peck, and William Scott Green (eds.), Encyclopedia of Judaism, Volume III, P-Z, 1374-1383. Leiden, Boston, Köln: Brill, (2000).

[13] Gutmann, J., "Synagogue Origins: Theories and Facts," in Joseph Gutmann (ed.), Ancient Synagogues the State of Research (Brown Judaic Studies 22), 1-6. Chico, CA: Scholars Press, (1981).

[14] Zeren, M. T., İzmir’de Sefarad Mimarisi ve Sinegoglar, İstanbul, Yalın Yayın, (2010).

[15] Türkoğlu, İ, “Anadolu'da Museviler I.” Arkeoloji ve Sanat, 22/ 65: 15-27, (2000).

[16] Brooten, B. J., "Inscriptional Evidence for Women As Leaders In The Ancient Synagogue," in Kent Harold Richards (ed.), Society of Biblical Literature 1981 Seminar Papers 117th Annual Meeting December 19-22, 1981, 10-17. San Francisco, California: Scholars Press, (1981).

[17] Milson, D., "Aspects of the Impact of Christian Art \& Architecture on Synagogues in Byzantine Palestine.” Ph.D. thesis, University of Oxford, Oxford, (2001). 
[18] Brooten, B J.., "Women Leaders in the Ancient Synagogue: Inscriptional Evidence and Background Issues,” Brown Judaic Studies 36:103-38. Chico: Scholars Press, (1982).

[19] Strange, J. F., "Ancient Texts, Archaeology as Text, and the Problem of the First Century Synagogue," in Howard Clark Kee and Lynn H. Cohick (eds.), Evolution of the Synagogue: Problems and Progress, 27-45. Harrisburg, Pennsylvania: Trinity Press International, (1999).

[20] Spigel, Chad, "Reconsidering The Question Of Separate Seating In Ancient Synagogues," Journal of Jewish Studies, vol. 63 no 1, 2012, 62-83. DOI: 10.18647/3072/JJS-2012.

[21] Mann, Vivian B. "Synagogues, Medieval and Modern," in Jacob Neusner, Alan J. Avery-Peck, and William Scott Green (eds.), The Encyclopedia of Judaism III, P-Z, 1383-97. Leiden, Boston, Köln: Brill, (2000).

[22] Safrai, H., "Women and the Ancient Synagogue," in Susan Grossman and Rivka Haut (eds.), Daughters of the King: Women and the Synagogue, 39-50. Philadelphia: The Jewish Publication Society, (1992).

[23] Ertürkmen, B. S. “Ankara Yahudi Mahallesi Birlik Sokak’ta Bulunan Ankara Sinagogu ile Albukrek ve Araf Konutlarının 19.yy Osmanlı Batılılaşması Bağlamında İncelenmesi.” Master's thesis, Gazi University, Ankara, (2013).

[24] Güleryüz, N., "İber'den Günümüze Türk Yahudilerinin 500 Yıllık Yolculuğu.” Görüş Dergisi Türkiye Yahudileri, Special Issue, 14-22, (2003).

[25] Göncüoğlu, S. F., "Haliç Yahudileri ve Sinagogları." In Dünü ve Bugünü ile Haliç Sempozyum Bildirileri, 139-65. Istanbul: Kadir Has University, (2004).

[26] Türkoğlu, İ., “Haliçin İki Yakasındaki Sinagoglar Üzerine Gözlemler,” In Dünü ve Bugünü ile Haliç Sempozyumu, 479-98. Istanbul: Kadir Has University, (2004).

[27] Kuzgun, Ş., Türklerde Yahudilik ve Doğu Avrupa Yahudilerinin Menşeii Meselesi, Hazar ve Karay Türkleri. Ankara: Alıç Matbaacılık, (1993).

[28] Internet: Encyclopaedia Britannica. "Christianity: The Church". https://global.britannica.com/topic/church-Christianity, (2017).

[29] Majeska, G. P., Russian Travelers to Constantinople in the Fourteenth and Fifteenth Centuries. Washington DC: Dumbarton Oaks, (1984).

[30] Taft, Robert F., "Women at Church in Byzantium: Where, When-And Why?" Dumbarton Oaks Papers, vol. 52, 1998, 27-87. DOI: 10.2307/1291777.

[31] Douglas, M., Purity and Danger, An Analysis of Concepts of Pollution and Taboo. London and New York: Routledge, Taylor and Francis, (2001).

[32] Gilchrist, R., Gender and Material Culture: The Archaeology of Religious Women. London and New York: Routledge, (1993).

[33] Stewart, C., Simpson's History of Architectural Development Vol. II, Early Christian, Byzantine and Romanesque Architecture. Longmans, Green And Co: London, New York, and Toronto, (1954).

[34] Doorn-Harder, N. V., "Christianity: Coptic Christianity," in Thomas Riggs (ed.), Worldmark Encyclopedia of Religious Practices 1, Religions and Denominations, 160-165. Thomson Gale, (2006). 
[35] Roeber, A. G., "Christianity: Eastern Orthodoxy," in Thomas Riggs (ed.), Worldmark Encyclopedia of Religious Practices 1, Religions and Denominations, 173-182. Detroit, MI: Thomson Gale, (2006).

[36] Freston, P., "Christian Congregation," in Peter B. Clarke (ed.), Encyclopedia of New Religious Movements, 118-120. New York: Routledge, (2006).

[37] Ortaylı, 1., Osmanlı İmporatorluğu'nda İktisadi ve Sosyal Değişim, Makaleler I. Ankara: Turhan Kitabevi, (2000).

[38] Samb, A., "Masdjid," in Bosworth, C.E., Van Donzel, E., Heinrichs, W.P., Pellat, C.H. (eds.), Encyclopedia of Islam VI, New Edition, 644-707. Leiden: Brill, 1991.

[39] Imam Hafiz Abu Dawud Sulaiman bin Ash'ath. English Translation of Sunan Abu Dawud I. Translated by Abu Ammar Yasir Qadhi. Riyadh: Darussalam Global Leader in Islamic Books, (2008).

[40] Söylemezoğlu, H. K., İslam Dini, İlk Camiler ve Osmanlı Camileri. İstanbul: İstanbul Teknik Üniversitesi Mimarlık Fakültesi Yayınları, (1954).

[41] Avc1-Erdemli, K., "Cami Mimarisinde Kadınların Yeri ve İstanbul Müftülügü Camilerin Kadınlar Bölümünü Güzelleştirme Projesi (3T Projesi)," in 1. Ulusal Cami Mimarisi Sempozyumu Gelenekten Geleceğe Cami Mimarisinde Çağdaş Tasarım ve Teknolojileri Bildiri Kitabı, 115-130, Ankara: Diyanet Vafk1 Yayınları, (2013).

[42] Internet: İlmihal I, “İman ve İbadetler”, Diyanet İşleri Başkanlığ1, 273-275, 1998. https://webdosya.diyanet.gov.tr/DiyanetAnasayfa/UserFiles/DiniBilgiler/ilmihal_cilt_1.pdf, (2019).

[43] Internet: Davudoğlu, A., Taşkesenlioğlu, M., Savaş, M., (trans.), İbn-i Âbidin Muhammed Emin, Reddü'l-Muhtar, $\quad$ "Namaz", Şamil $\quad$ Yayınları, 2017. http://www.islamiyontem.net/kitaplar/Turkce\%20Fikih/Fetvalar/reddulmuhtar/index.htm, (2019).

[44] Erzen, J. N., "Reading Mosques: Meaning and Architecture in Islam." The Journal of Aesthetics and Art Criticism, Special Issue: The Aesthetics of Architecture: Philosophical Investigations into the Art of Building, 69(1):125-131, (2011).

[45] Internet: İlmihal, Namaz, İmamlık ve Cemaat, Ch. 161, http://www.kuran.com.tr/ilmihal/imamlik-vecemaat, (2019).

[46] Internet: Zandberg, E., Women's Sections in Shul: Separate, Unequal. Haaretz, 23 Sep. 2014. http://www.haaretz.com/jewish/features/.premium-1.617295, (2017).

[47] Paliou, E., "Visibility Analysis in 3D Built Spaces: A New Dimension to the Understanding of Social Space," in Eleftheria Paliou,Undine Lieberwirth, and Silvia Polla (eds.), Spatial analysis \&social spaces: Interdisciplinary approaches to the Interpretation of Prehistoric \& Historic Built Environments, 91-114. Berlin and Boston: De Gruyter, (2014).

[48] Sargın, H.,"Havra, Kilise ve Cami İç Mekânlarina İbadethane Kimliğini Kazandıran Mekânsal İmge ve Sembollerine İlişkin Ortak Kavramlar.” Master’s thesis, Anadolu University, Eskisehir, (2012).

[49] Internet: Joseph, N. B., Mechitzah: Separate Seating in the Synagogue, My Jewish Learning, 2011. http://www.myjewishlearning.com/article/mehitzah-separate-seating-in-the-synagogue, (2017).

[50] Mathews, T. F., The Early Churches of Constantinople Architecture and Liturgy. University Park: Pennsylvania State University, (1971). 
[51] Tanman, M. B., "Mahfil," in Türkiye Diyanet Vakfi İslam Ansiklopedisi, 27: 331-333. Ankara: Türkiye Diyanet Vakfı Yayınları, (2003).

[52] Çam, N., Müezzin Mahfilleri ve Gaziantep Camilerinin Ahşap Müezzin Mahfili. In 9th International Congress of Turkish Art. Ankara: Ministry of Culture, 541-556, (1995).

[53] Holmes-Katz, M., Women in the Mosque: A History of Legal Thought and Social Practice. New York: Columbia University Press, 17-110, (2014)

[54] Arslantaş, N. “Abbasîler ve Fatimîler Döneminde Yahudiler (132-656/750-1258).” Ph.D. thesis, Marmara University, Istanbul, (2007).

[55] Özonur, Z., "İsrail İç Siyasetinde Ordu-Havra İlişkisi.” Master’s thesis, Kocaeli University, Kocaeli, (2009).

[56] Wortzman, H., "Jewish Women in Ancient Synagogues: Archaeological Reality vs. Rabbinical Legislation." Women in Judaism: A Multidisciplinary e-Journal, 5(2): 1-17, (2008). 